\title{
January 1997 Flooding in Northern Nevada- Was This a "100-Year Flood"?
}

U.S. Department of the Interior-U.S. Geological Survey

The January 1997 flooding in northern Nevada and California caused river flows to reach record flood levels. Streamflows in the Carson, Truckee, and Walker Rivers (figure 1) were monitored at gaging stations by the U.S. Geological Survey (USGS) and many exceeded previous records set in 1955 and 1986 (Wells, 1958; Pupacko and others, 1988). The gaging station on the West Walker River below Little Walker River near Coleville, Calif. (station number 10296000), had recorded data from two floods during the past 60 years with recurrence intervals of almost 50 years and two other floods with recurrence intervals equal to or greater than 100 years (figure 2). These data are based on a flood-frequency analysis using data through 1995. A second analysis completed for the West Walker River, including the preliminary peak from the 1997 flood, indicated that only one peak exceeded the 100-year flood frequency. The previous two floods that had been near the 50-year recurrence interval are now ranked between 20 and 50 years on the basis of the new data.

\section{How Are Flood-Recurrence Intervals Designated?}

The average time, expressed in years, between extreme floods equal to or greater than a specified magnitude at a particular location is referred to as the recurrence interval of the flood (Paulson and others, 1991, p. 586). The chance of a given flow being exceeded once in any given year is expressed as an annual probability. A flood having a recurrence interval of 100 years has 1 chance in 100 , or a 1 -percent probability of happening in any given year. Similarly, a flood with a recurrence interval of 50 years has a 1 -in-50 or 2-percent chance of happening in any year; 10 years is 1 -in- 10 or 10-percent chance.

Briefly, the 100-year flood is a statistical designation for a specific streamflow that has a 1-percent chance of being equalled or exceeded during any single year. Streamflow statistics are computed using annual peak data. These annual peaks are obtained either from continuous-record gaging stations or from peak stage at crest-stage sites.

The statistical computation is completed using as many years of data as possible. The reliability of the 100-year flood designation increases with additional data. A designation using 10 years of data generally would be less reliable than one using 50 or 75 years of data. Even with 75 years of streamflow data, the 100-year flood magnitude needs to be re-evaluated periodically as more streamflow data are collected or if changes in watershed conditions or climate are suspected.

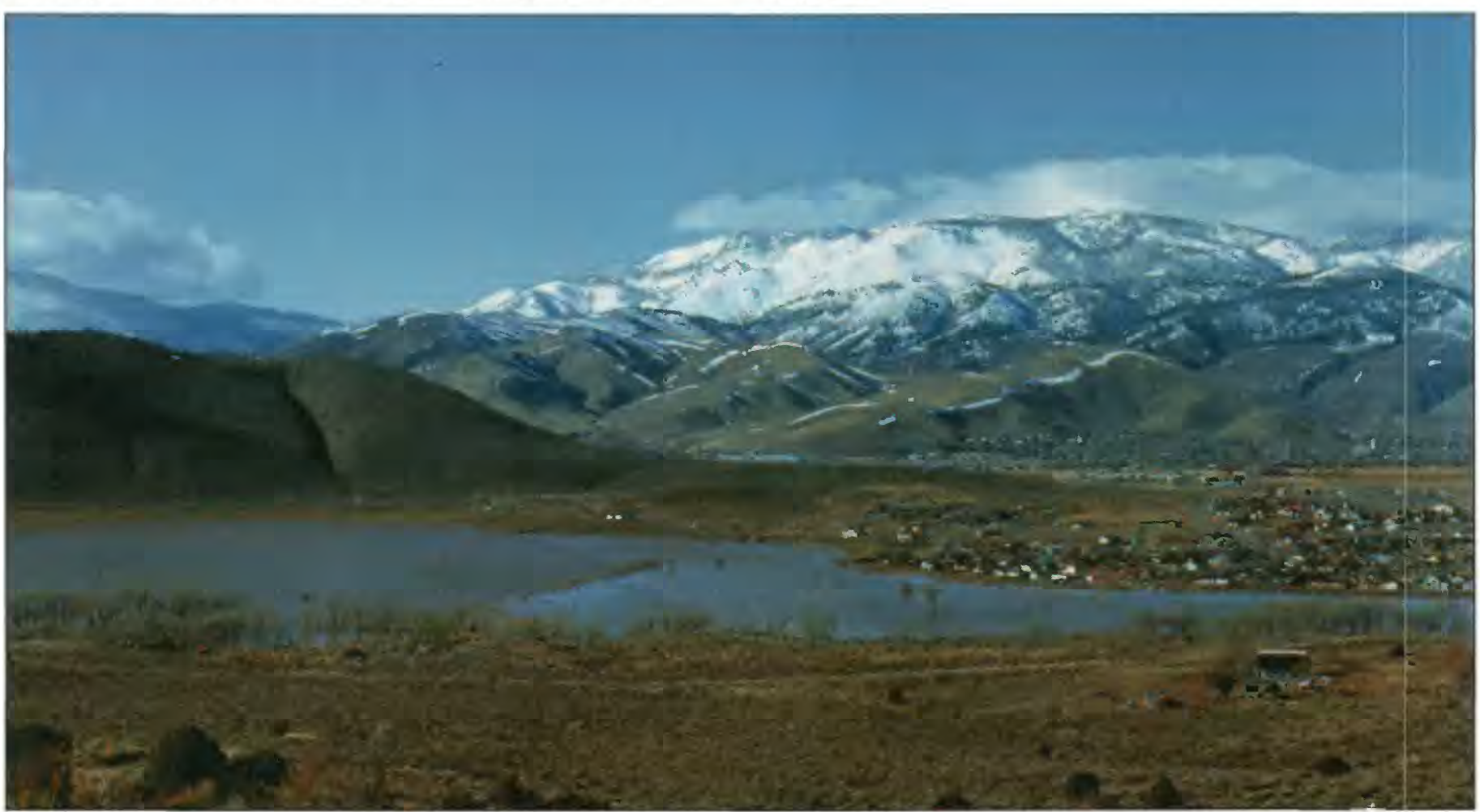

Looking westward toward Carson City, January 3, 1997. Carson River (middle of photograph) flows from left to right. Carson River has overflowed its banks flooding fields and other nearby lowland areas (photograph by Russell W. Plume, U.S. Geological Survey). 
Looking northeast from right bank at bridge over the Carson River near Carson City, September 10, 1996. Streamflow is about $\mathbf{5 5}$ cubic feet per second, which is near the average low flow (photograph by Rick Pruszka, U.S. Geological Survey)

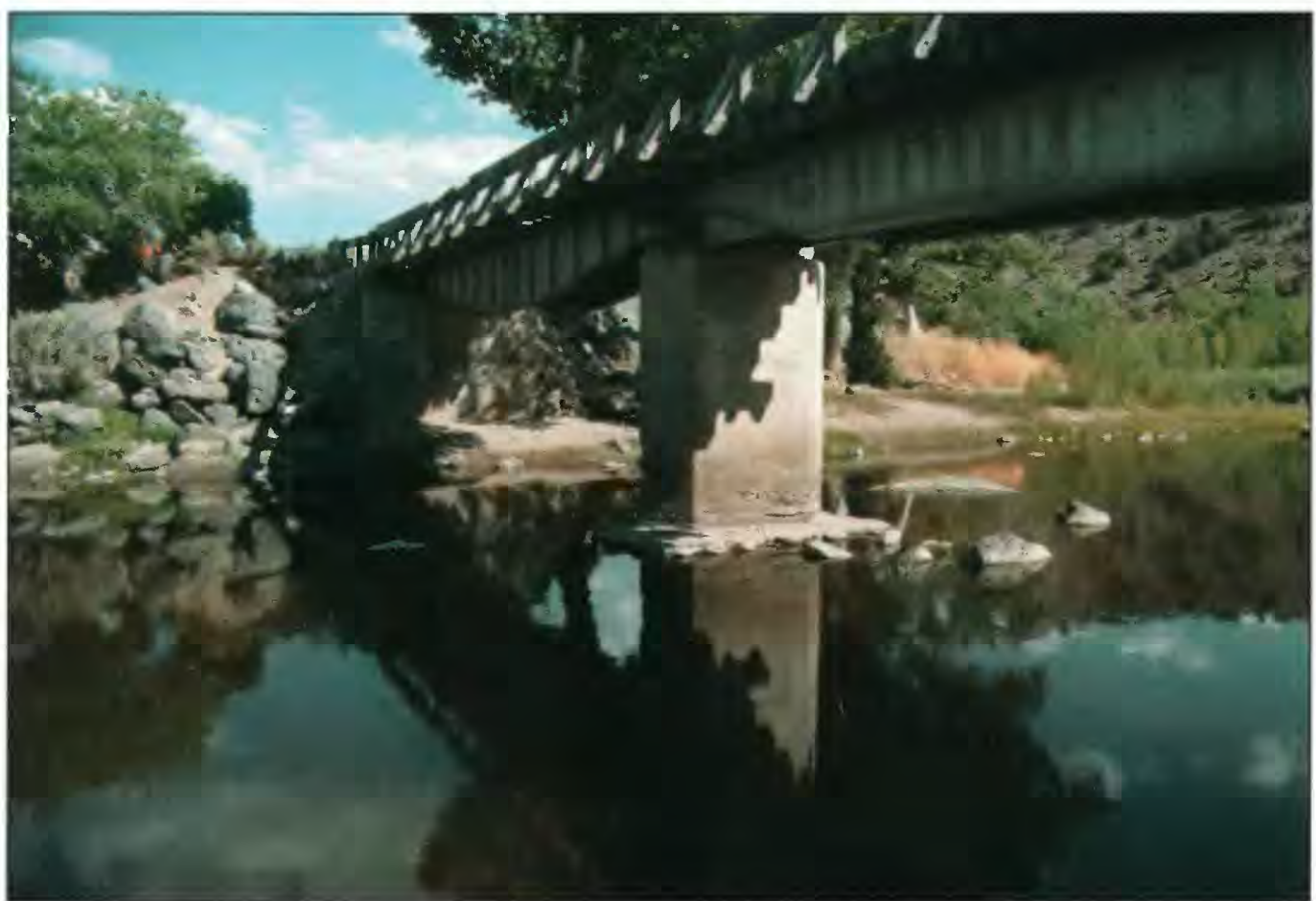

Flood-frequency analyses done by the Federal Government are standardized so that the analyses can better be compared among agencies. Federal interagency committees sponsored by the U.S. Water Resources Council (1967) and the U.S. Interagency Advisory Committee on Water Data (1982) established a recommended procedure for determining flood magnitude and frequency.

\section{Do 100-Year Floods Really Happen Every 100 Years?}

The phrase "100-year flood" is misleading to many people who mistakenly believe this means that such a flood should occur only once every 100 years. A 100-year flood can occur during any year or more than once in a given year.

A simple analogy on the chance of recurrence of floods is the toss of a coin. The chance of tossing heads with a coin is one out of two, or 50 percent. Thus on average, one out of every two tosses will result in heads. Does this mean a person will get tails every other toss? Possibly, but probably not. Could a person toss heads three times in a row? Certainly. If the statistical sample were five tosses, would a good estimate of the probability be determined? No, but the more times the coin is tossed, the better the estimate will be of the probability. Similarly with flooding, the more observations, the better the probability of determining the level of a $100-$ year flood.

\section{Do Flood Designations Change Through Time?}

The frequency of flooding should be re-evaluated as more data are obtained through the years, or when the river channel is modified (for example, by dam construction) or urban
Figure 1. Geographic and hydrologic features of the Truckee, Carson, and Walker River Basins. 


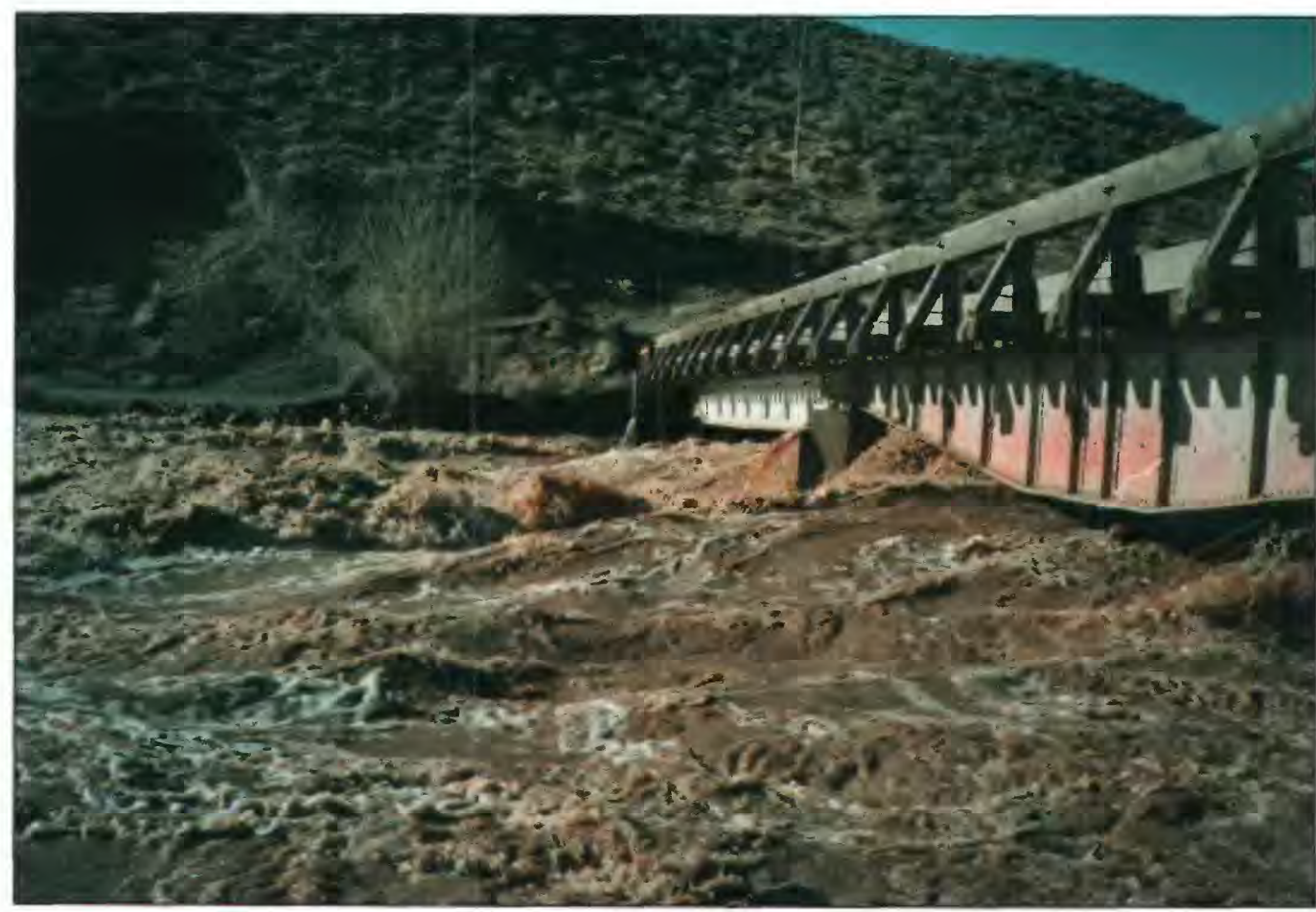

Looking southwest from left bank at bridge over Carson River near Carson City, January 3,1997 . Streamflow is about 27,500 cubic feet per second, which is greater than a 50-year flood but less than a 100-year flood on the basis of data from 1939 to 1997 (photograph by Rhea Williams, U.S. Geological Survey). development takes place within the flood plain and the flow of water in the river is affected. Inclusion of streamflow data collected during the 1997 high flows on the Carson River at Carson City (station number 10311000) have affected the 100-year flood statistics and indicate that the 100-year flood is probably greater than previously reported (figure 3 ). The previous 100-year flood designation was calculated using data from 1939 through 1995 and was statistically determined to be 27,700 cubic feet per second $\left(\mathrm{ft}^{3} / \mathrm{s}\right)$. Including the January 1997 flow data in the calculation caused the 100-year flood designation to shift to a higher streamflow value of $33,100 \mathrm{ft}^{3} / \mathrm{s}$. The peak streamflow was $28,000 \mathrm{ft}^{3} / \mathrm{s}$ (provisional) on January 2, 1997, at the Carson River at Carson City. Thus, using the pre-1997 statistics, this January 1997 peak was approximately equal to a 100-year flood; but after including the 1997 peak flow data, this is less than a 100 -year flood. A similar analysis for selected gaging stations on the Truckee River indicates the recurrence interval is slightly less than 50 years for the January 1997 flood (Berris and others, 1997). The reliability of the 50-year or 100 -year flood designation for these and other stations is maintained only with continued streamflow monitoring.

\section{Flood-Prone Areas}

Areas affected by past floods have been mapped by the Federal Emergency Management Agency and other government agencies. These maps provide approximate boundaries of areas subject to inundation by a 100-year flood. Even if the magnitude of the 100-year flood, for example, remained constant, conditions in or near the stream channel could raise or lower the water-surface level corresponding to that discharge. Through time, rivers change because of the natural scouring or filling of river channels. As these changes occur, the stage (height) of the river can remain the same but the river may contain more or less water because of the amount of scour or fill that has taken place through time.

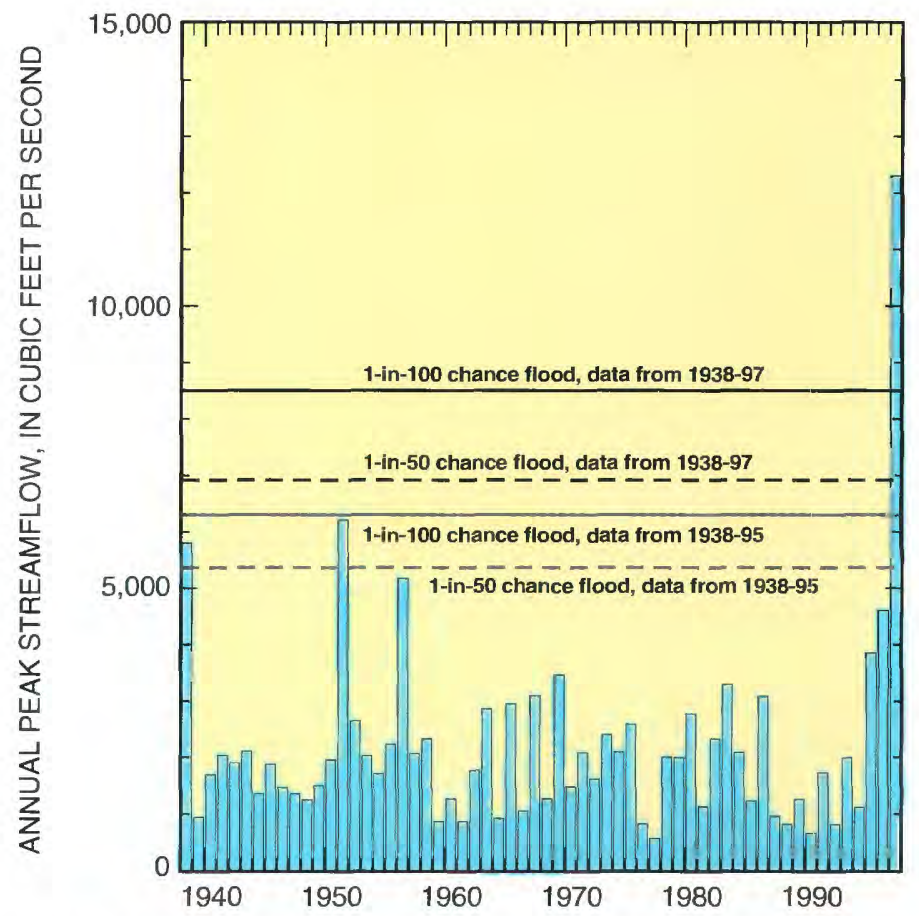

Figure 2. Annual peak streamflow data for West Walker River below Little Walker River near Coleville, Calif., gaging station. Streamflow data collected during the January 1997 flood indicate that estimated streamflow of 1-in-100 chance flood (maximum yearly peak) increased over that from data collected during 1938-95. The peaks from May 1996 and the January 1997 flood are provisional and subject to revision. 


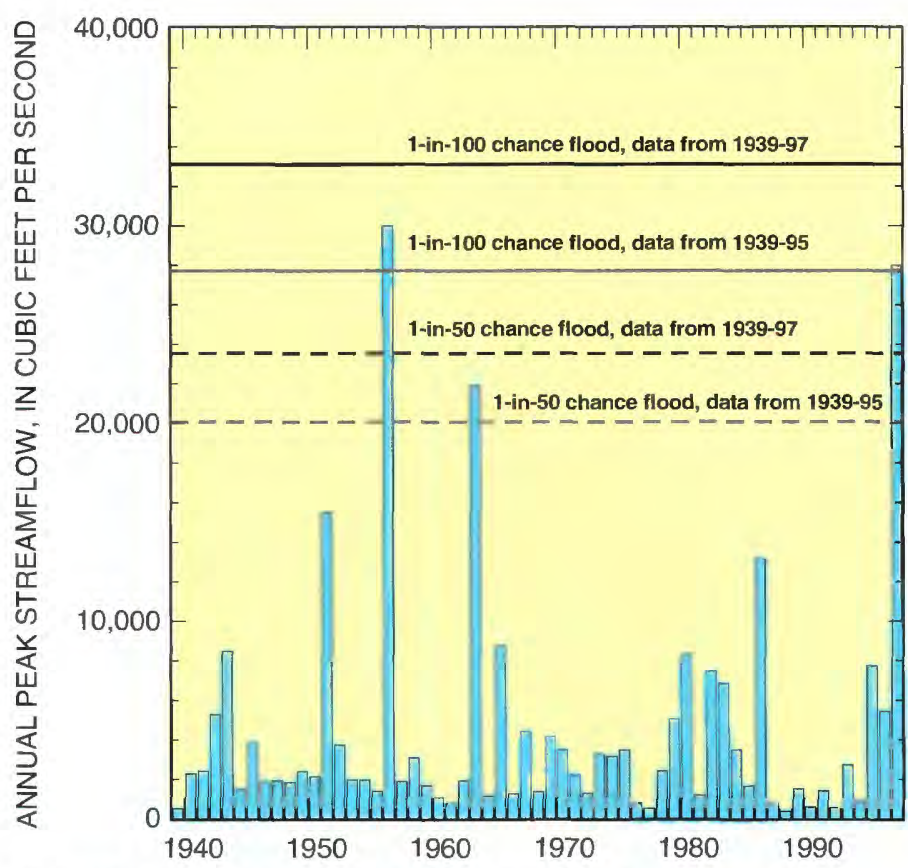

Figure 3. Annual peak streamflow data for Carson River at Carson City, Nev., gaging station. Streamflow data collected during the January 1997 flood indicate that estimated streamflow of 1-in-100 chance flood (maximum yearly peak) increased over that from data collected during 1939-95. The peaks from May 1996 and the January 1997 flood are provisional and subject to revision.

\section{Data Essential For Understanding Floods}

The systematic collection of hydrologic data is needed to help understand floods. Continued collection of streamflow data and occasional hydraulic studies that define river levels associated with a specific discharge are needed to update flood boundaries. Staff of the USGS measure streamflow in rivers and creeks throughout the State during normal flows and major floods. At sites inaccessible during floods, the height of "high-water marks" from debris and silt is surveyed, and this information is used with standard engineer ing techniques to calculate the maximum (peak) streamflow during the flood. The previously noted examples of the changes for flood-level designations on the West Walker and Carson Rivers show how essential continued data collection is to the understanding of floods.

-Kerry T. Garcia

\section{Glossary}

(from Langbein and Iseri, 1961; Bauer and others, 1996)

Annual peak. The peak discharge for a given year.

Cubic feet per second $\left(\mathrm{ft}^{3} / \mathrm{s}\right)$. A unit expressing the rate of discharge. One cubic foot per second is equal to the discharge of a stream of rectangular cross section 1 foot wide and 1 foot deep with water flowing at an average velocity of 1 foot per second. It is equivalent to about 450 gallons per minute. The peak flow of the Carson River at Carson City during the January 1997 flood was about $28,000 \mathrm{ft}^{3} / \mathrm{s}$, which would fill the the Washington Monument in less than 1 minute.
Discharge. The volume of water (or more broadly, volume of fluid plus suspended sediment) that passes a given point within a given time.

Flood peak. The highest value of the stage or discharge reached by a flood.

Flood plain. The lowland that borders a river, usually dry but subject to flooding.

Gaging station. A particular site on a stream, canal, lake, or reservoir where systematic observations of gage height or discharge are obtained.

Stage. The height of a water surface above an established reference; sometimes referred to as gage height.

Streamflow. The discharge that occurs in a natural channel, usually expressed in cubic feet per second.

\section{References Cited}

Bauer, D.J.. Foster, B.J., Joyner, J.D., and Swanson, R.A., 1996, Water resources data, Nevada, water year 1995: U.S. Geological Survey Water-Data Report NV-95-1, 734 p.

Berris, S.N., Hess, G.W., Taylor, R.L., and Bohman, L.R., 1997, Flood-control effects of Truckee River Basin reservoirs, December 31, 1996, through January 4, 1997, California and Nevada: U.S. Geological Survey Fact Sheet FS-037-97, 4 p.

Langbein, W.B., and Iseri, K.T., 1961, General introduction and hydrologic definitions: U.S. Geological Survey Water-Supply Paper 1541-A, $29 \mathrm{p}$.

Paulson, R.W., Chase, E.B., Roberts, R.S., and Moody, D.W.. comps., 1991, National water summary 1988-89-Hydrologic events and floods and droughts: U.S. Geological Survey WaterSupply Paper 2375, 591 p.

Pupacko, Alex, La Camera, R.J., Reik, M.M., and Wood, D.B., 1988, Water resources data, Nevada, water year 1986: U.S. Geological Survey Water-Data Report NV-86-1, 263 p.

U.S. Interagency Advisory Committee on Water Data, 1982 , Guidelines for determining flood flow frequency: Hydrology Subcommittee Bulletin 17B, 28 p. plus appendixes. Available only from National Technical Information Services, U.S. Department of Commerce, Springfield, VA 22161, accession number PB-86-157278/AS.

U.S. Water Resources Council, 1967, A uniform technique for determining flood flow frequency: Washington, D.C., Hydrology Subcommittee Bulletin 15, 15 p.

Wells, J.V.B., 1958, Surface-water supply of the United States, 1956-Part 10, The Great Basin: U.S. Geological Survey WaterSupply Paper 1444, 231 p.

\section{For more information please contact:}

Public Information Assistant

U.S. Geological Survey

333 W. Nye Lane, Rm 203

Carson City, NV 89706

tel. (702) 887-7649

fax (702) 887-7629

usgsinfo_nv@usgs.gov

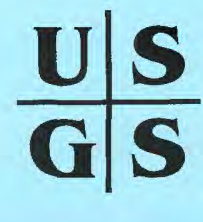

Publication assistance by Robin L. Bunch and Graham A. Patterson 